\title{
Fluidity-dependent $\mathrm{Mg}^{2+}$-ATPase activity in membranes from Leishmania donovani promastigotes
}

\author{
Mitali DUTTA, Rajyasree BANDYOPADHYAY, Chandramallika GHOSH and Makul K. BASU* \\ Leishmania Group, Biomembrane Division, Indian Institute of Chemical Biology, Calcutta 700032, India
}

\begin{abstract}
The state of the lipid phase of the membrane plays a key role in the exposure of various receptors, antigens and enzymes on the membrane surface. The fluidity of membranes of Leishmania donovani promastigotes was monitored by two independent methods, i.e. influx of sterol from liposomes and removal of phospholipids by treatment with phospholipase $\mathrm{C}$. The altered sterol/phospholipid ratio, in both cases, provided evidence that the activity of the functionally important membrane-bound enzyme $\mathrm{Mg}^{2+}-\mathrm{ATPase}$ is modulated by the state of the lipid phase of the membrane.
\end{abstract}

\section{INTRODUCTION}

Cholesterol exchange techniques involving liposomes of various cholesterol/phospholipid molar ratios have been used previously by other investigators to alter the cholesterol content of biological membranes [1-4]. The cholesterol/phospholipid ratio can also be altered by removal of phospholipids by appropriate enzymes [5]. The altered ratio has been shown to affect the microviscosity of the membrane and thus influence the exposure of receptors [6], antigens [7-9] and enzymes $[5,6]$. In the present paper, we report the modification of Leishmania donovani promastigote membranes by two independent techniques, i.e. sterol exchange and phospholipase $\mathrm{C}$ treatment. These powerful techniques of controlled alteration of membrane microviscosity have never been utilized previously to study the properties of the parasite membrane in general. The activity of the membrane-bound enzyme $\mathrm{Mg}^{2+}$-ATPase has been analysed and found to correlate well with the microviscosity of the membrane lipid. Thus a highly ordered lipid environment may be detrimental to the activity of this enzyme, which is reportedly present on the parasite membrane surface [10].

\section{MATERIALS AND METHODS}

Phospholipase C (from Clostridium perfringens), sucrose, anthroyl stearate, cholesterol, ergosterol and ATP were products of Sigma Chemical Co., St. Louis, MO, U.S.A. Egg lecithin was purchased from the CSIR Centre for Biochemicals, New Delhi, India. $\left[{ }^{3} \mathrm{H}\right]$ Cholesterol was a product of Amersham International, Amersham, Bucks., U.K. Diphenylhexatriene (DPH) was purchased from Aldrich Chemical Co., Milwaukee, WI, U.S.A. All other reagents were of analytical grade. The promastigotes of $L$. donovani UR-6, a recently isolated clinical strain, were used throughout. The cells were grown at $22^{\circ} \mathrm{C}$ on blood agar slants containing $1 \mathrm{~g}$ of glucose, $1.5 \mathrm{~g}$ of agar, $3.7 \mathrm{~g}$ of brain heart infusion powder and 2-3 $\mathrm{ml}$ of rabbit blood in a total volume of $100 \mathrm{ml}$.

\section{Isolation of parasite membranes}

L. donovani promastigotes from the mid-to-late log phase of their growth were used for membrane preparation, essentially using Dwyer's method [11] with some modifications. The promastigotes were suspended in

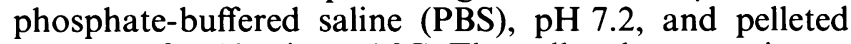
at $6000 \mathrm{~g}$ for $10 \mathrm{~min}$ at $4{ }^{\circ} \mathrm{C}$. The pelleted promastigotes were washed twice with PBS and adjusted to $5 \times 10^{8}$ cells $/ \mathrm{ml}$ in ice-cold Tris containing $1 \mathrm{~mm}$-EDTA and $1 \mathrm{~mm}$-phenylmethanesulphonyl fluoride, $\mathrm{pH} \mathrm{8.0.} \mathrm{The}$ promastigotes were allowed to swell for $1.5 \mathrm{~h}$ at $4^{\circ} \mathrm{C}$ and were then freeze-thawed twice to lyse the cells. This was monitored by microscopic examination. After centrifuging at $5000 \mathrm{~g}$ for $30 \mathrm{~min}$ in a Sorvall $\mathrm{HB} 4$ rotor, the pellets were suspended in $10 \mathrm{ml}$ of $5 \%$ sucrose $(0.146 \mathrm{M})$ in $0.02 \mathrm{M}$-Tris $/ \mathrm{HCl}$ containing $3 \mathrm{~mm}-\mathrm{MgCl}_{2}$, $\mathrm{pH} 8.0$ (TM-buffer). The rest of the procedure was similar to that used by Dwyer [11], except that the discontinuous sucrose-density-gradient centrifugation was carried out at $42000 \mathrm{~g}$ for $4 \mathrm{~h}$ in a swing-bucket $\mathrm{AH}$ 627 rotor of a Sorvall ultracentrifuge. The purified membrane, which appeared as a white band at the interface between the $1.23 \mathrm{M}$ - and $1.52 \mathrm{M}$-sucrose layers, was removed, diluted with TM-buffer and washed again at $45000 \mathrm{~g}$ for $30 \mathrm{~min}$ using the same rotor. The pellet so obtained was used as purified membrane for subsequent experiments.

\section{Phospholipase $\mathbf{C}$ treatment}

The parasite membrane thus prepared was suspended in $50 \mathrm{~mm}$-Tris buffer, $\mathrm{pH} \mathrm{7.2,} \mathrm{containing} 2 \mathrm{~mm}-\mathrm{CaCl}_{2}$ (TC-buffer). Equal amounts of the purified membrane $(1 \mathrm{~mm}$ of protein) were treated with different concentrations of phospholipase $\mathrm{C}$ at $37^{\circ} \mathrm{C}$ for $1 \mathrm{~h} \mathrm{[5]}$ with appropriate controls. At the end of the incubation the reaction mixtures were diluted $(\times 30)$ with TC-buffer and centrifuged at $47000 \mathrm{~g}$ for $30 \mathrm{~min}$ in a swing-bucket rotor AH-627. The modified membrane thus pelleted was resuspended in a small volume of $50 \mathrm{~mm}-\mathrm{Tris} / \mathrm{HCl}$,

Abbreviations used: DPH, diphenylhexatriene; PBS, phosphate-buffered saline; SUV, small unilamellar vesicles; MLV, multilamellar vesicles: AS, anthroyl stearate.

* To whom correspondence should be addressed. 
$\mathrm{pH} 7.2$, and used immediately for assay of $\mathrm{Mg}^{2+}$-ATPase and fluidity measurements.

\section{Liposome preparation}

Liposomes were prepared by the method of Gregoriadis \& Ryman [12] with little modification. In short, egg lecithin and cholesterol or ergosterol were taken in a round-bottom flask at a molar ratio of $2: 3$. The lipids were dissolved in chloroform/methanol $(2: 1$, $\mathrm{v} / \mathrm{v})$. A thin dry film of these compounds was made on the surface of the round-bottom flask by evaporating the organic solvent in an atmosphere of $\mathrm{N}_{2}$. The film was allowed to swell for $1 \mathrm{~h}$ at room temperature in sterile PBS and sonicated for $30 \mathrm{~min}$ at a $4{ }^{\circ} \mathrm{C}$ in an ultrasonicator (MSE Soniprep 150 Sonicator). The sonicated material was centrifuged for $1 \mathrm{~h}$ at $105000 \mathrm{~g}$ to separate small unilamellar vesicles (SUV) from multilamellar vesicles (MLV). Liposomes made from $\left[{ }^{3} \mathrm{H}\right]$ cholesterol were prepared in exactly the same way but with the addition of a trace of $\left[{ }^{3} \mathrm{H}\right]$ cholesterol to the lipid mixture.

\section{Incubation of promastigotes with sterol-enriched liposomes}

The SUV preparation, after exposure to ultraviolet light for $1 \mathrm{~h}$, was used for incubation in a $1: 1(\mathrm{v} / \mathrm{v})$ ratio with the promastigotes $\left[(2.5-5.0) \times 10^{8}\right.$ cells $/ \mathrm{ml}$ of medium]. The incubation was done overnight at $37^{\circ} \mathrm{C}$. After the incubation, excess liposomes were washed off and the lipid-modified parasites were subjected to membrane isolation as detailed before.

The SUV preparation (cholesterol/phospholipid molar ratio 1.5) made from egg lecithin, cholesterol and $\left[{ }^{3} \mathrm{H}\right]$ cholesterol (trace) was used in a similar fashion to modify the promastigotes. The modified promastigotes, after being washed twice with PBS, were re-incubated with a fresh SUV preparation having a lower cholesterol/ phospholipid molar ratio of 0.5 to study the exchange of $\left[{ }^{3} \mathrm{H}\right]$ cholesterol from cholesterol-rich modified promastigotes to a cholesterol-poor SUV preparation. A measured portion of the incubation mixture was spun down every $1 \mathrm{~h}$ and the supernatant was examined for ${ }^{3} \mathrm{H}$ radioactivity.

\section{$\mathrm{Mg}^{2+}$-ATPase assay}

The parasite membrane preparations were routinely dialysed for $1 \mathrm{~h}$ at $4{ }^{\circ} \mathrm{C}$ against 1 litre of distilled water to remove any remaining phosphates. The $\mathrm{Mg}^{2+}$-ATPase assay was carried out according to the method of Riordan et al. [13]. Inorganic phosphate was quantified by the method of Ames \& Dubin [14]. Enzyme activity is expressed as $\mu \mathrm{mol}$ of $\mathrm{P}_{\mathrm{i}}$ liberated/min per $\mathrm{mg}$ of protein.

\section{Chemical analyses}

Lipids from the promastigote membrane were extracted by the method of Kates [15]. Lipid phosphorus was determined by the method of Norton \& Autilio [16]. Total sterol was determined by the procedure of Abel et al. [17]. Protein estimation was carried out according to Lowry et al. [18] using bovine serum albumin as standard.

\section{Measurement of fluidity}

The lipid fluidity of promastigote membranes was determined by fluorescence depolarization measurements $[1,6]$ using anthroyl stearate (AS) and DPH as fluorescence probes. The measurements of fluorescence anisotropy were carried out in a fluorescence polarization spectrometer (Perkin Elmer, IS-3) at room temperature using an excitation wavelength of $365 \mathrm{~nm}$ and an emission wavelength of $430 \mathrm{~nm}$ for DPH. For AS, the excitation and emission wavelengths used were $362 \mathrm{~nm}$ and $440 \mathrm{~nm}$ respectively. The fluorescence anisotropy $r$ was calculated using the equation:

$$
r=\left(I_{\|}-I_{\perp}\right) /\left(I_{\|}+2 I_{\perp}\right)
$$

where $I_{\|}$and $I_{\perp}$ are the fluorescence intensities oriented respectively parallel and perpendicular to the direction of polarization of the excited light. The microviscosity parameters $\left[\left(r_{0} / r\right)-1\right]^{-1}$ were calculated in each case knowing the maximal limiting fluorescence anisotropy, $r_{0}$, which for DPH is 0.362 [19] and for AS is 0.295 [20]. The microviscosity parameter used by us [6] and various other workers $[8,19,20]$ is a convenient way of quantifying the measurements, but this is strictly for the purpose of comparison and is not an absolute measurement of microviscosity.

\section{RESULTS AND DISCUSSION}

The total sterol/phospholipid molar ratio of $L$. donovani promastigote membranes has been altered by two independent techniques: (i) sterol influx and (ii) removal of phospholipids by phospholipase C. Membrane microviscosity is altered in both cases. The hydrophobic interaction between sterols and fatty acyl chains of phospholipids brings the acyl chains closer together; most of the membrane proteins are then vertically displaced towards the aqueous layers, increasing the exposure of receptors, antigens and enzymes [5-9]. In the case of digestion with phospholipase $\mathrm{C}$, it is suggested that the enzymically formed diacylglycerols, which are supposed to remain in position in the membrane, migrate into discrete pools [21]. Electron micrographs have provided evidence for the separation of diacylglycerol droplets which remain associated with the membranes [22]. The results of experiments analysing promastigote membrane $\mathrm{Mg}^{2+}$-ATPase as a function of treatment with phospholipase $\mathrm{C}$ are shown in Fig. 1 . $\mathrm{Mg}^{2+}$-ATPase activity was seen to increase by 2 -fold over the control on exposure to $5 \mu \mathrm{g}$ of enzyme $/ \mathrm{mg}$ of membrane protein. When a large amount (e.g. $10 \mu \mathrm{g})$ of phospholipase $\mathrm{C}$ was added, a decrease rather than an increase in $\mathrm{Mg}^{2+}$ ATPase activity was noticed. The effect on the microviscosity of the promastigote membrane after

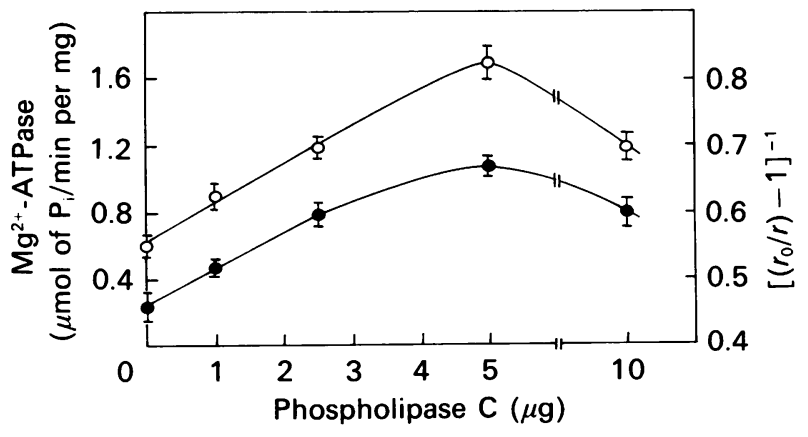

Fig. 1. Membrane microviscosity (O) and specific activity of $\mathrm{Mg}^{2+}$-ATPase $(\mathrm{O})$ as a function of treatment with phospholipase $\mathbf{C}$ 
Table 1. Dependence of $\mathrm{Mg}^{2+}$-ATPase activity on the microviscosity of $\boldsymbol{L}$. donovani promastigote membranes after exchange of sterols from liposomes

Results are shown as means \pm S.D. (for controls $(n=5)$ and for modified preparations $(n=3)$.

\begin{tabular}{|c|c|c|}
\hline \multirow{2}{*}{$\begin{array}{l}\text { Promastigote } \\
\text { membrane }\end{array}$} & {$\left[\left(r_{0} / r\right)-1\right]^{-1}$} & \multirow{2}{*}{$\begin{array}{c}\text { Specific } \\
\text { activity } \\
\text { of } \\
\mathrm{Mg}^{2+}-\mathrm{ATPase} \\
(\mu \mathrm{mol} \text { of } \\
\mathrm{P}_{\mathrm{i}} / \mathrm{min} \\
\text { per } \mathrm{mg})\end{array}$} \\
\hline & DPH & \\
\hline \multirow{2}{*}{$\begin{array}{l}\text { Untreated control } \\
\text { Modified after } \\
\text { cholesterol enrich- } \\
\text { ment* }^{*}\end{array}$} & \multirow{2}{*}{$\begin{array}{ll}0.46 \pm 0.02 & 0.82 \pm 0.06 \\
0.52 \pm 0.04 & 0.98 \pm 0.02\end{array}$} & $0.60 \pm 0.05$ \\
\hline & & $0.80 \pm 0.15$ \\
\hline $\begin{array}{l}\text { Modified after } \\
\text { ergosterol enrichment } \dagger\end{array}$ & $0.58 \pm 0.02 \quad 1.17 \pm 0.13$ & $1.20 \pm 0.02$ \\
\hline \multicolumn{3}{|c|}{$\begin{array}{l}* \text { Incubated with liposomes of cholesterol/phospholipid } \\
\text { molar ratio }=1.5 \text {. } \\
\quad+\text { Incubated with liposomes of ergosterol/phospholipid } \\
\text { molar ratio }=1.5 \text {. }\end{array}$} \\
\hline
\end{tabular}

treatment with increasing amounts of phospholipase C is also shown in Fig. 1. Microviscosity increased with the increasing amounts of phospholipase $\mathrm{C}$ used for digestion. A maximum increase of about $50 \%$ over the control was noticed on exposure to $5 \mu \mathrm{g}$ of enzyme $/ \mathrm{mg}$ of membrane protein. As noticed before, when a large amount $(10 \mu \mathrm{g})$ of phospholipase $C$ was added, a decrease rather than an increase in microviscosity was seen. The reason for these anomalous effects of high phospholipase $\mathrm{C}$ concentrations remains obscure. It is possible that when a large amount of enzyme is used, the enzymically formed diacylglycerols form separate phases which might interfere with both the enzyme assay and the microviscosity measurement. However, the results of both the experiments are shown in Fig. 1 for comparison.

The sterol/phospholipid molar ratio of the erythrocyte membrane has been altered by sterol-exchange techniques involving liposomes $[1,3]$. Both lipid composition [23] and microviscosity [5] of macrophage membranes have been altered by the same technique involving liposomes of a higher sterol/phospholipid molar ratio. In order to ascertain whether a similar mechanism operates in parasite membranes, an attempt was made to modify promastigote membranes by incubation with liposomes of a higher sterol/phospholipid molar ratio, an alternative approach not involving phospholipid digestion. As the major sterol in L. donovani promastigotes is reported to be ergosterol [23], liposomes made from both cholesterol and ergosterol have been used for comparison. The dependence of $\mathrm{Mg}^{2+}$-ATPase activity on the microviscosity of the $L$. donovani promastigote membrane, which has been modified by liposome treatment, are shown in Table 1. The fluorescent probes AS and DPH have been used for fluorescence depolarization measurement. From Table 1, it is obvious that for the control and two modified preparations, the values of the microviscosity parameter $\left[\left(r_{0} / r\right)-1\right]^{-1}$ are higher for DPH compared with AS. When compared with the control, the percentage change for the modified preparations was also higher with DPH than that found for AS. Whether

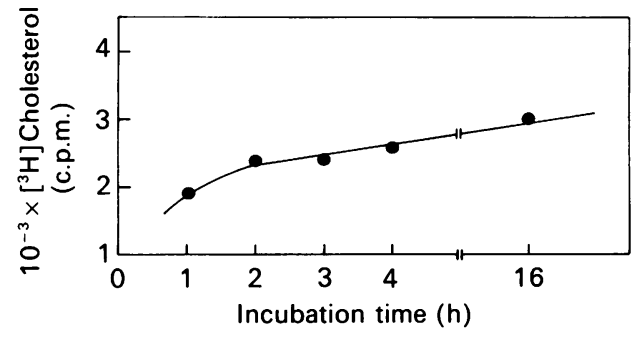

Fig. 2. Transfer of $\left[{ }^{3} \mathrm{H}\right]$ cholesterol from modified promastigotes to unlabelled liposomes

The cholesterol/phospholipid molar ratio of the liposomes was 0.5 .

a heterogeneous fluidity does exist in the promastigote membrane remains an open question, as the interpretation of the microviscosity parameter in terms of molecular properties is not justified unless time-resolved measurements are performed.

When the specific activity of $\mathrm{Mg}^{2+}$-ATPase in the control preparation is compared with that in the cholesterol-enriched preparation or the ergosterolenriched preparation, a $33 \%$ increase is noticed in the former case and a $50 \%$ increase in the latter case. The major sterol in $L$. donovani promastigote is ergosterol [24], and therefore the exchange of sterol may be faster with ergosterol liposomes, inflicting greater changes on both the microviscosity of the membrane and the specific activity of $\mathrm{Mg}^{2+}$-ATPase. Cholesterol-enriched or ergosterol-enriched membranes were analysed chemically for the sterol/phospholipid molar ratio. Compared with the sterol/phospholipid molar ratio of the control membrane (approx. 0.5), that of the cholesterol- or ergosterolenriched membrane was found to be higher (0.8-1.0). To demonstrate that sterol or cholesterol from liposomes exchanges with that of promastigote membranes, the liposomes were prepared from egg lecithin and a mixture of cholesterol and $\left[{ }^{3} \mathrm{H}\right]$ cholesterol in a molar ratio of $2: 3$ and the promastigotes were incubated overnight (approx. $16 \mathrm{~h}$ ) with these liposomes at $37^{\circ} \mathrm{C}$. On the following day, the excess liposomes were washed off and, after thorough washing, radioactivity bound to the promastigotes was determined. To confirm that cholesterol from liposomes exchanges with that of promastigote membranes, and the liposomes are not simply attached to the membrane, cholesterol-enriched washed parasites were re-incubated with the liposomes (cholesterol/phospholipid 0.5) made without $\left[{ }^{3} \mathrm{H}\right] \mathrm{chol}-$ esterol at $37^{\circ} \mathrm{C}$. Portions were withdrawn every $1 \mathrm{~h}$ up to $4 \mathrm{~h}$ and then finally after $16 \mathrm{~h}$, and were counted for radioactivity after removing the parasites by low-speed centrifugation. The counts increased with time of incubation (Fig. 2). It is noteworthy that $60 \%$ of the total counts, bound to a definite number of promastigotes, was leached out slowly during the incubation overnight $(16 \mathrm{~h})$.

This relationship between lipid fluidity and enzyme activity $[5,6]$ is the reverse of that found for several other membrane enzymes $[25,26]$ and hence may be unique. Even for this enzyme, its location within the membrane seemed to be very crucial [27]. From the results of microviscosity measurements, it appears that higher membrane microviscosity probably facilitates the 
normal functioning of this enzyme. When membrane microviscosity is increased, it is reported $[1,4]$ that vertical displacement of membrane proteins takes place, exposing receptors at the membrane surface. Similarly, higher membrane microviscosity may displace the enzyme to some extent so that all substrate sites are exposed at the surface. However, the other possible mechanisms should not be neglected. For example, the location of the enzyme in the membrane, the asymmetric distribution of membrane phospholipids between the two halves of the bilayers and the fluidity-dependent conformational change in the enzyme might also play a role.

Financial assistance from United Nations Development Programme, Council of Scientific and Industrial Research, India, and Department of Atomic Energy, India, is gratefully acknowledged.

\section{REFERENCES}

1. Borochov, H. \& Shinitzky, M. (1976) Proc. Natl. Acad. Sci. U.S.A. 73, 4526-4530

2. Chapman, H. A. \& Hibbs, J. B. (1977) Science 197, 282-285

3. Cooper, R. A., Leslie, M. H., Fishkoff, S., Shinitzky, M. \& Shattil, S. J. (1978) Biochemistry 17, 327-331

4. Borochov, H., Abbott, R. E., Schachter, D. \& Shinitzky, M. (1979) Biochemistry 18, 251-255

5. Riordan, J. K. (1980) in Membrane Fluidity: Biophysical Techniques and Cellular Regulation (Kates, M. \& Kuksis, A., eds.), pp. 119-129, Humana Press, Clifton, NJ.

6. Mukherjee, S., Ghosh, C. \& Basu, M. K. (1988) Exp. Parasitol. 66, 18-26

7. Shinitzky, M. \& Souroujon, M. (1979) Proc. Natl. Acad. Sci. U.S.A. 76, $4438-4440$

8. Basu, M. K., Flamm, M., Schachter, D., Bertles, J. F. \& Maniatis, A. (1980) Biochem. Biophys. Res. Commun. 95, $887-893$
9. Flamm, M., Basu, M. K., Schachter, D., Bertles, J. F. \& Maniatis, A. (1982) Blood 60, 340-345

10. Dwyer, D. M. \& Gottlieb, M. (1983) J. Cell Biochem. 23, $35-45$

11. Dwyer, D. M. (1980) J. Protozool. 27, 176-182

12. Gregoriadis, G. \& Ryman, B. E. (1972) Biochem. J. 129, 123-133

13. Riordan, J. R., Slavik, M. \& Kartner, N. (1977) J. Biol. Chem. 252, 5449-5455

14. Ames, B. N. \& Dubin, D. T. (1960) J. Biol. Chem. 235, 769-775

15. Kates, M. (1972) in Techniques of Lipidology (Work, T. A. \& Work, E., eds.), pp. 351-352, Elsevier, New York

16. Norton, W. T. \& Autilio, L. A. (1966) J. Neurochem. 13, 213-222

17. Abel, I. I., Levy, B. B., Brodies, B. B. \& Kendall, F. E. (1952) J. Biol. Chem. 195, 357-366

18. Lowry, O. H., Rosebrough, N. J., Farr, A. L. \& Randall, R. J. (1951) J. Biol. Chem. 193, 265-275

19. Shinitzky, M. \& Barenholz, Y. (1974) J. Biol. Chem. 249, 2652-2657

20. Schachter, D. \& Shinitzky, M. (1977) J. Clin. Invest. 59, 536-548

21. Colley, C. M., Zwaal, R. F. A., Roelofsen, B. \& Van Deenen, L. L. M. (1973) Biochim. Biophys. Acta 307, 74-82

22. Finean, J. B. \& Martonosi, A. (1965) Biochim. Biophys. Acta 98, 547-553

23. Gilbreath, M. L., Swatz, G. M., Alving, C. R., Nacy, C. A., Hoover, D. I. \& Meltzer, M. S. (1985) Infect. Immun. 47, 567-569

24. Goad, I. J., Holz, G. G. \& Beach, D. H. (1984) Mol. Biochem. Parasitol. 10, 161-170

25. Farias, R. N., Bloj, B., Boreno, R. D., Sineriz, F. \& Truceo, R. E. (1975) Biochim. Biophys. Acta 415, 231-257

26. Sanderman, H., Jr. (1978) Biochim. Biophys. Acta 515, 209-237

27. Roelofsen, B. \& Van Deenen, L. L. M. (1973) Eur. J. Biochem. 40, 245-257

Received 13 September 1989/9 November 1989; accepted 27 November 1989 